Article

\title{
Why Do Households Depend on the Forest for Income? Analysis of Factors Influencing Households' Decision-Making Behaviors
}

\author{
Mazhar Biland ${ }^{1}$, Alam Zeb ${ }^{1,2}$, Ayat Ullah ${ }^{3,4, *}$ and Harald Kaechele ${ }^{3,5}$ \\ 1 Department of Forestry, Shaheed Benazir Bhutto University Sheringal Dir (Upper), \\ Khyber Pakhtunkhwa 18050, Pakistan; bilandmazhar@gmail.com (M.B.); zeb@ualberta.ca (A.Z.) \\ 2 Department of Renewable Resources, University of Alberta, 751 General Services Building, \\ Edmonton, AB T6G 2H1, Canada \\ 3 Research Area 2 "Land Use and Governance”, Working Group: Sustainable Land Use in Developing \\ Countries, Leibniz Centre for Agricultural Landscape Research (ZALF), Eberswalder Straße 84, \\ 15374 Müncheberg, Germany; Harald.Kaechele@zalf.de \\ 4 Department of Agricultural Extension Education and Communication, The University of Agriculture, \\ Peshawar, Khyber Pakhtunkhwa 25130, Pakistan \\ 5 Eberswalde University for Sustainable Development, Schicklerstraße 5, 16225 Eberswalde, Germany \\ * Correspondence: Ayat.Ullah@zalf.de
}

check for updates

Citation: Biland, M.; Zeb, A.; Ullah, A.; Kaechele, H. Why Do Households Depend on the Forest for Income? Analysis of Factors Influencing Households' Decision-Making Behaviors. Sustainability 2021, 13, 9419. https://doi.org/10.3390/ su13169419

Academic Editor: Sharif Ahmed Mukul

Received: 1 July 2021

Accepted: 20 August 2021

Published: 22 August 2021

Publisher's Note: MDPI stays neutral with regard to jurisdictional claims in published maps and institutional affiliations.

Copyright: (c) 2021 by the authors. Licensee MDPI, Basel, Switzerland. This article is an open access article distributed under the terms and conditions of the Creative Commons Attribution (CC BY) license (https:/ / creativecommons.org/licenses/by/ $4.0 /)$.

\begin{abstract}
Using survey information of 150 randomly selected households across 21 villages of the forest-rich district of Swat, Pakistan, this study assessed households' decision-making behaviors in depending on income from nearby forested land using socio-economic attributes. The evidence from the study may aid in making the existing policies be better targeted toward families that depend on the forest for income. Descriptive statistics and econometric techniques such as logit and tobit were used to analyze the data. Respondent households obtained the highest share of their income from off-farm activities (37\%) and least from forest activities (16\%). Fuelwood constitutes the biggest share $(66 \%)$ of forest income, followed by medical plants $(20 \%)$ and fodder $(13 \%)$. We found that households with more physical assets, more family members working in off-farm jobs, and households earning more income from off-farm jobs were significantly and negatively associated with households decision to depend on forest income and total income obtained. We also found that households with less distance to the market and membership to joint forest management committees (JFMCs) were significantly and negatively associated with households' total income obtained. However, household size was significantly and positively related to households' decision of forest dependency. The study recommends the creation of off-farm opportunities and inclusion of local people in the management of forests through establishment of JFMCs, particularly for large and poor families.
\end{abstract}

Keywords: decision-making behavior; socio-economic attributes; forest income dependency; total income obtained

\section{Introduction}

In hilly areas of the world, people depend on the forest ecosystem for their livelihood [1,2]. Households living close to forests collect a wide range of forest products for home use and sale, particularly fuelwood, building materials, wild foods, and medicinal plants. Forest income is defined as the gross value of forest products obtained from forests both for home use and sale, minus the costs of inputs used in the extraction. Research studies reported forest contribution as being six to forty-five percent of household total income $[3,4]$. Forest-related income play an important role in poverty alleviation and rural development $[5,6]$. Particularly, since the last three decades, this role received enormous international attention [7], mainly because of the positive association of poverty prevalence in forest regions [8] and the global consensus about the greater potential of forests 
in poverty alleviation. Forests contribute to poverty reduction through providing food, fuelwood, construction timber, and forest-based products [9].

The main sources of forest income are fuelwood extraction and non-timber forest products' (NTFPs) collection [10]. Though fuelwood is mainly collected as a source of energy for home use, it has a significant effect on poverty reduction [11]. This is because households also collect fuelwood for sale in nearby markets to supplement their income. Most farm families use forest product income to fill income gaps [12]. Though the contribution of forest income in the majority of cases is supplemental, the sales of NTFPs in some cases have been reported to contribute $25 \%$ of household total income [13].

Yet, not all households depend on income from forests. Some of the recent studies by [14-18] have studied households' socio-economic characteristics and their decisionmaking behavior in depending on forests for income. Among these, [14] found that household size, sex of household head, and agriculture landholding size were the significant determinants of a household's decision to rely on forests for income. However, [16] found that age and education significantly affected household reliance on forest income as compared to household size, head sex, and landholding size. Some other studies by [17-19] have found that age, education, household size, physical assets, distance to market, off-farm income, and JFMC (joint forest management committee) membership significantly influenced household dependency on forest income.

Predominantly, forest income is important for the rural poor and they rely more on income from the forest than wealthy households do [14]. As income increases, households looking to buy forest products tend to rely more on the market than collecting it themselves [20,21]. It is a well-known fact that communities with better employment opportunities outside of the forest sector and who are both highly educated and well connected to the external market ensure forest protection through lessening pressure on forest resources [18].

However, studies linking livelihood dependency and its impact on local forests observed that local livelihood has been placing pressure on forests, resulting in deforestation and forest degradation [22]. Households' dependency on forest income is a function of households' socio-economic and demographic characteristics [2]. Opposite to this, in developing countries, deforestation and degradation in most cases are attributed to state failure in the management of forest resources [23-25]. For this reason, most government interventions are in the form of protected areas delineation, improvement of forest governance, and regional logging prohibitions [22,26]. Failure to consider factors outside of the forest sector could result in inappropriate forest policies that may lead to unsustainable activities such as deforestation and overuse of forests and rangelands, resulting poverty prevalence. Factors outside of the forest sector that could decrease pressure on forests include generating off-farm income opportunities, promotion of eco-friendly tourism, and promoting sustainable agriculture and livestock development.

Research and policy action that considers multiple factors including those outside of the forest sector could contribute to slowing down deforestation without severely compromising the income of forest-dependent communities. In addition, forest-dependent households are not homogenous in characteristics and needs, and thus for conservation programs to be successful, they must take into account the different socio-economic contexts and households' needs $[27,28]$. Thus, understanding the socio-economic attributes of forestdependent communities will help in releasing pressure on forests by providing inputs to the formation of sound policies that will serve the twin objectives of forest protection and poverty alleviation. In this study, Swat, a forest-rich district in the Himalaya HinduKush region in which forests are being threatened by sever livelihood pressures [29], is considered for a socio-economic analysis of factors affecting household reliance on forests for income. The overall objective of this study is to link the household decision-making behavior in depending on forests for income with their socio-economic attributes and farm level characteristics. 
Specifically, this study verified the following hypotheses:

Hypothesis 1. Bigger families depend more on forest income because they have more workers and more households to feed.

Hypothesis 2. Families with members employed in off-farm jobs depend less on forest income.

Hypothesis 3. Due to limited livelihood options, asset-poor households depend more on forest income.

Hypothesis 4. Households living close to the market are less dependent on income from forests as they have other options of employment.

Hypothesis 5. Households who are members of joint forest management committees (JFMCs) are unlikely to depend on forest resources as compared to non-members.

Several studies have demonstrated the role of forest income in the livelihood of forest inhabitants in different parts of Pakistan [22,29-34]. However, very few attempts were made to assess the socioeconomic determinants of households' decision-making behaviors in depending on forest income. Therefore, this paper contributes to the debate regarding who around a forest depends on the forest for income. Using the case of the forest-rich district Swat, Pakistan, the paper addresses this issue empirically. This study is also important in the broader context as it uses a primary household dataset from the HinduKush Himalayan $(\mathrm{HKH})$ region of Pakistan to discover human-environment interactions at the household level. The policy recommendations of this study is equally applicable to the whole Himalayan-Hindu Kush region that covers an area of 4.2 million $\mathrm{km}^{2}$ and is home to about 210 million people.

\section{Theoretical Framework}

This study used the livelihood framework (LF) as an organizing approach to assess the effects of various assets available to the households on their dependence on forest income. The framework provides a general method for thinking about the various factors and their interactions that influence households' decisions to depend on forest income, as seen in Figure 1. The LF is one of the most frequently used frameworks in micro-level studies focusing on household economic strategies [35], income diversification [36], human migration [37], and poverty [38]. The framework is also used in studies focusing on deforestation and agriculture expansion [3,39]. The livelihood framework was developed by the British Department for International Development (DFID) to coordinate and improve organization efforts to eliminate poverty.

The core idea of livelihood framework is based on the availability of and access to assets that determine the strategies people can adopt to attain the livelihood outcomes in a given policy, with regard to institutional and processes constraints [40]. Most of the rural people in developing countries maintain diversified livelihood strategies as they cannot obtain sufficient food from any single strategy to survive and also to reduce the risk of vulnerability [41]. They depend on agriculture, livestock, forest products, and wage labor [42]. Forest products include the collection of fuelwood, timber, wild nuts, and medicinal plants both for domestic use and sale.

Access to more remunerative strategies is determined by the asset status of households, i.e., those with more assets tend to have a range of options to switch between strategies [43]. Households' assets are grouped into five categories: natural, human, physical, social, and financial. Natural capital includes land, forests, water, and pastures [44]. Human capital includes skill, knowledge, labor, health status, and leadership potential that varies with household size [44]. Physical capital includes agriculture land, farm tools, and machines, as well as other households' valuable items [44]. Social capital includes membership to government or non-government organizations, ethnicity, and social networking and 
connections. The strategies adopted based on the available assets are mediated by the processes and context [44]. According to [39,44], these processes and contexts include: (1) institutions that determine rules of access and use; (2) accessibility to market which affects transportation cost and relative prices; and (3) the external environment referred to as the vulnerability context, e.g., death, human and livestock loss, job loss, etc.

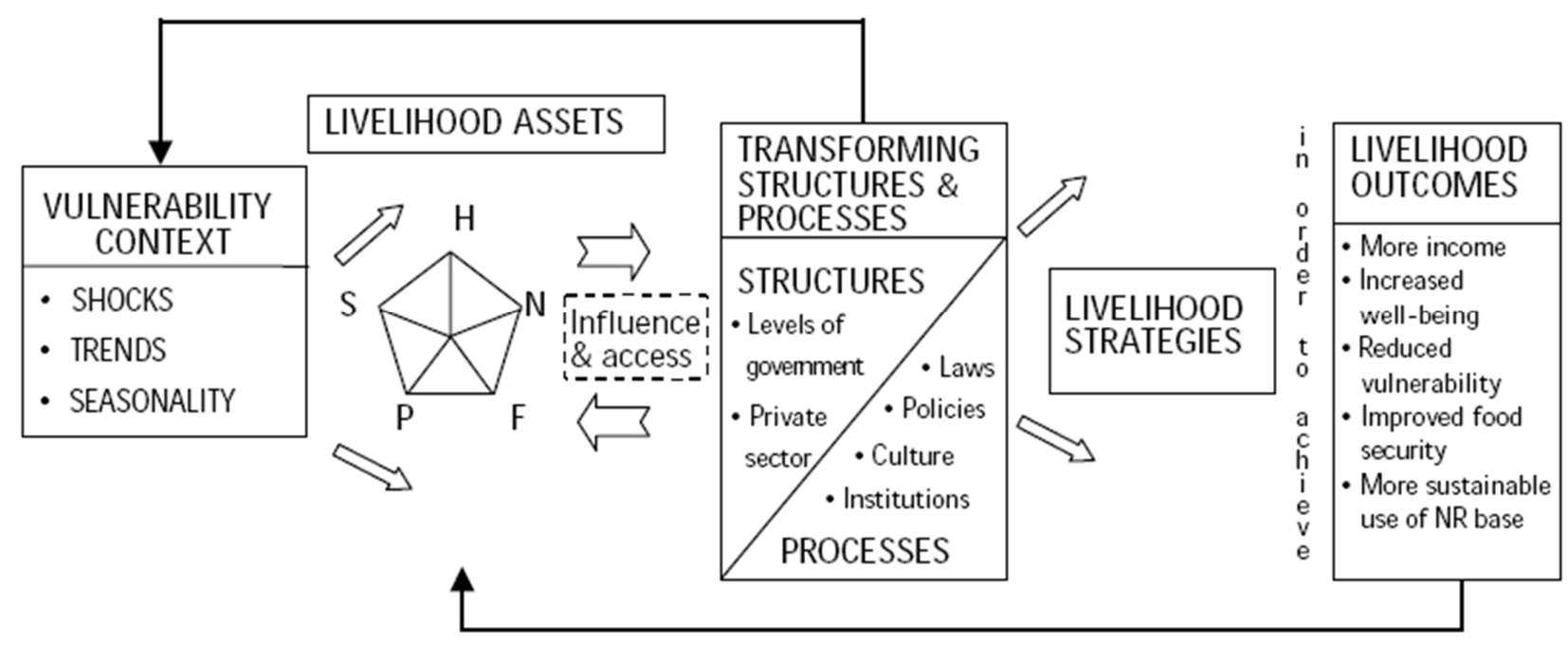

Figure 1. The sustainable livelihoods framework of the United Kingdom's Department for InternaTable 1999.

\section{Data and Methods}

\subsection{Study Area Profile}

The Swat district is a high mountainous part of the Khyber Pakhtunkhwa (KP) province located in the high-altitude of the HKH region of Pakistan, as seen in Figure 2. The district is situated between $34^{\circ} 30^{\prime} 00^{\prime \prime}$ to $35^{\circ} 50^{\prime} 00^{\prime \prime} \mathrm{N}$ and $72^{\circ} 05^{\prime} 00^{\prime \prime}$ to $72^{\circ} 50^{\prime} 00^{\prime \prime} \mathrm{E}$. The area altitude range is from 500 to $6500 \mathrm{~m}$ above sea level (a.s.l) and falls in the moist and dry temperate region of the Pakistan forest classification. Major forest species found in the area are Pinus wallichiana (blue pine), Pinus gerardiana (edible pine), and Cedrus deodara (cedar) both in pure and mixed forms. The district covers an area of $5037 \mathrm{~km}^{2}$ with a total population of 2.30 million growing at a high annual rate of 3.37\% [45]. A higher percentage $(86 \%)$ of the district's population is living in rural areas [29]. Swat is chosen purposely for the present research study because it is one of the most forest-dense districts of the country with a diverse set of ecological, biophysical, and socio-economic characteristics [29]. The watershed of the area is large and influences the water basin of various hydropower stations. There are three major ethnic groups in the Swat Valley. These are: (1) Pathans (Khan), Pashto-speaking and practicing sedentary agriculture; (2) Kohistani, Kohistani-speaking and practicing agriculture and transhumant herding; and (3) Gujars, Gujri speaking and practicing nomadic herding. Gujars are the most underprivileged people of the area and heavily depend on livestock production.

\subsection{Data Collection}

Data was collected during the summer season from July to September 2019 using the survey instrument of the Poverty Environment Network (PEN), available online (www.cifor.org/pen) (accessed on 28 June 2019). Data was collected from first-hand sources using the household survey method. The survey questions were focused on the primary household income derived from various sources such as forest product extraction, agricultural production, livestock production, and off-farm activities, with special consideration to various forms of income collected both from cash and home consumption. The ethics approval for the research study was obtained through the Institutional Ethical Committee (IEC) at Shaheed Benazir Bhutto University (reference number). 

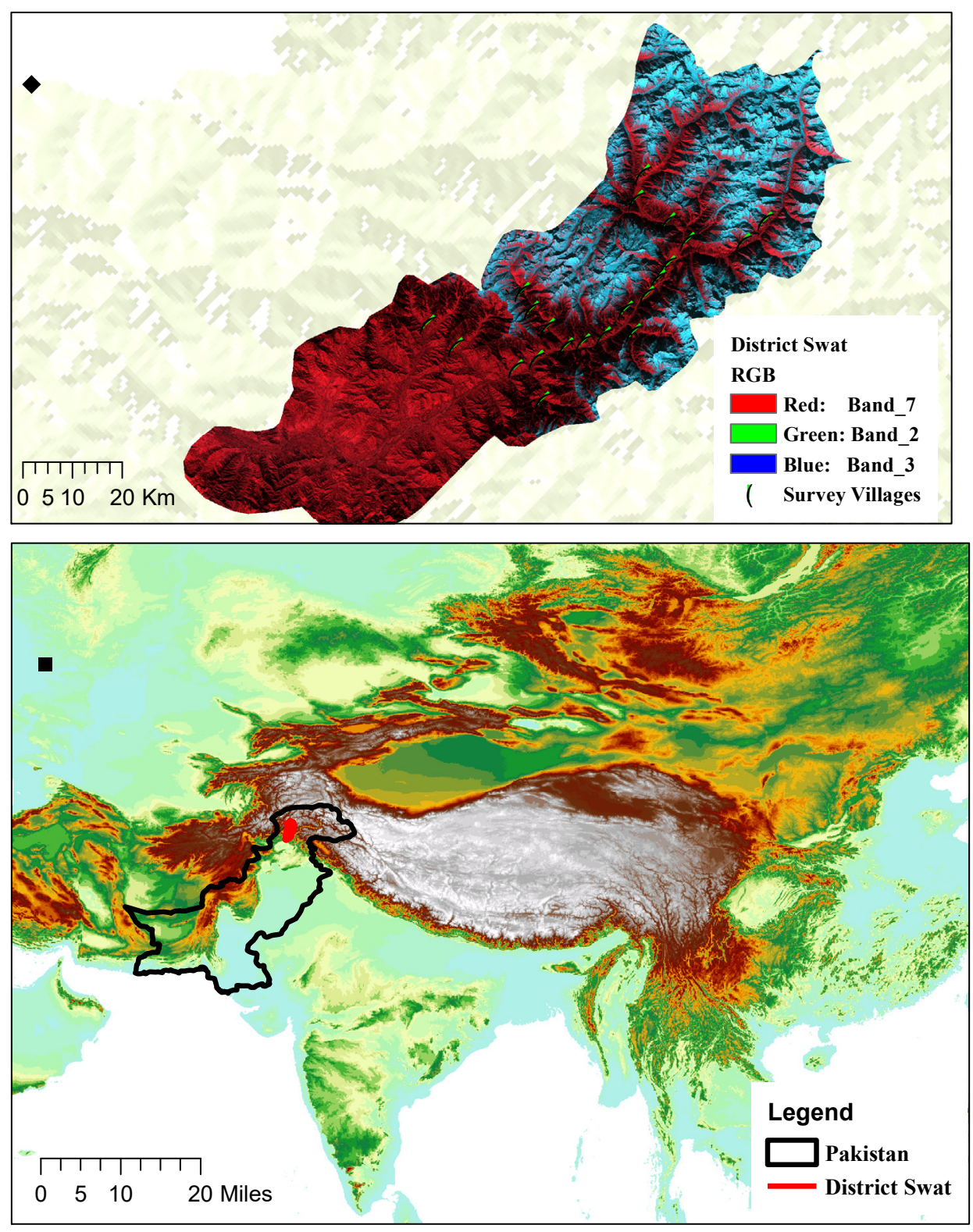

Figure 2. The location of Pakistan on HKH map (bottom) and Landsat image of the study area (top).

IEC/2019/AC/01). Informed written consent was obtained from all households interviewed. We interviewed 150 households from 21 villages of 5 sub-divisions of the Swat district (Table 1). The number of households from each village were selected using proportionate sampling techniques. The villages were purposely selected for this study. We included villages that were close to forests and villages that were close to the market. In addition, we included villages with and without established JFMCs. In the selected households, 99 respondents were dependent on forest income and 51 were not.

\subsection{Income Calculation}

This study adopted the PEN definition of household income [46] that considers household income as a reward of labor and capital used in an owned production/business or directly sold in a market. It also included transfer payments such as remittance, pensions, and other government payments as part of household income. Household total income is defined as the sum of cash and subsistence income derived from major income categories. Subsistence income is the market value of products consumed by the households. 
Table 1. Surveyed villages, total number of households in each village and sampled households from each village.

\begin{tabular}{|c|c|c|c|}
\hline Sub-Divisions & Villages & Total Households & Sampled Households (\%) \\
\hline \multirow{6}{*}{ Behrain } & Aryanay & 6225 & 6 \\
\hline & Laykot & 3433 & 3 \\
\hline & Chail & 6052 & 6 \\
\hline & Torwal & 2848 & 3 \\
\hline & Mankiyal & 5155 & 5 \\
\hline & Tirat & 21,870 & 21 \\
\hline \multirow{5}{*}{ K. Khela } & Jari/Pia & 12,593 & 12 \\
\hline & khair Abad & 2002 & 2 \\
\hline & Miandam & 15,095 & 14 \\
\hline & Sainay & 3141 & 3 \\
\hline & Jokhtai & 7180 & 7 \\
\hline \multirow{4}{*}{ Matta } & Lalkoo & 5855 & 6 \\
\hline & Landighari & 6616 & 6 \\
\hline & Sakhra & 13,456 & 13 \\
\hline & Wainy & 4858 & 5 \\
\hline \multirow{4}{*}{ Kabal } & Delay & 1625 & 2 \\
\hline & Dadahara & 6720 & 6 \\
\hline & Dagay & 6506 & 6 \\
\hline & Akhonkaly & 2882 & 3 \\
\hline \multirow{2}{*}{ Barikot } & Aboha & 13,256 & 13 \\
\hline & Shamozi & 7987 & 8 \\
\hline Total & & 155,355 & 150 \\
\hline
\end{tabular}

For the income calculation, we focused on four major income categories people pursue in the area: forest, livestock, agriculture, and off-farm incomes following the PEN survey instrument definitions. The formula is as follows: total household income $=\Sigma$ (forest income + agriculture income + livestock income + off-farm income). Total annual household income was determined by the following equation.

$$
\mathrm{HTI}=\sum_{t=1}^{i}(\mathrm{Xi})
$$

where HTI is household total annual income and $\mathrm{Xi}_{\mathrm{i}}$ is the various income categories.

Forest income consists of households' income from the sale or self-consumption of wood or wood-based products harvested/collected from the nearby forests and government payments such as forest royalty. This information from the households was collected at the time of the field survey. Households in the study area collected fuelwood, timber, honey, fodder, medicines, fruits, and vegetables. Forest income is calculated by multiplying the quantities of the products collected and their per unit monetary values.

Livestock income includes households' income from the sale or self-consumption of livestock or livestock-based products. Household agriculture income comprises income from the sale or owned use consumption of grains grown on household-owned or rented land. It also includes income from orchard production. Off-farm income is a broad category in this case that includes wages, salaries, and net income from self-employment other than farm, pension, and foreign remittances.

The final income calculated for a household is the net income of each category, which is the gross income value minus all the purchased inputs including hired labor. 


\subsection{Variables Used and Hypothesis}

We used the livelihood framework (LF) to gather data on all relevant socio-economic and demographic aspects of households' life and their interactions that influence their decisions to depend on income from nearby forested land [3,39]. Availability of and access to assets is the core theme of the livelihood framework [44]. Available assets in an area determine the likely strategies people adopt in the existing policy and institutional setting [40,44]. In hilly areas, forests are an important livelihood strategy.

The dependent and independent variables used in the analysis and their expected relationship are summarized in Table 2. A binary variable regarding whether or not households depend on income from forests and a continuous variable regarding the total income obtained were used as dependent variables in the analysis. The predictor variables include households' demographics as well as socio-economic and financial aspects explained as in livelihood framework.

Table 2. List of predictor variables that may influence the extraction of income from forests. The + and - sign is assigned to indicate the anticipated direction of the relation between the predictors and response variables.

\begin{tabular}{|c|c|c|}
\hline Variables & Definition and Unit of Measurement & Expected Sign \\
\hline \multicolumn{3}{|l|}{ Dependent Variables } \\
\hline Forest income (Yes/no) & Whether or not households receive income from the forest & \\
\hline Forest Income (Rs) & How much income households receive from the forest & \\
\hline \multicolumn{3}{|l|}{ Independent variables } \\
\hline \multicolumn{3}{|l|}{ Demographic variables } \\
\hline Household size & Total number of individuals in the household & $+/-$ \\
\hline Male/female ratio & Male/female ratio in the household & - \\
\hline \multirow[t]{2}{*}{ Family type } & 1. Nuclear & + \\
\hline & 2. Joint & $+1-$ \\
\hline Age of head & Household age in years (years) & - \\
\hline Education of head & Years of schooling (years) & - \\
\hline Off-farm employment & Number working in off-farm sector (people) & - \\
\hline \multicolumn{3}{|l|}{ Social variables } \\
\hline JFMC (membership) & Membership of forest organization $(0 / 1)$ & - \\
\hline Ethnicity & Membership of large ethnic group (0/1) & $+/-$ \\
\hline \multicolumn{3}{|l|}{ Physical variables } \\
\hline \multirow[t]{2}{*}{ Physical assets } & Value of household implements and other & \\
\hline & large items in Pakistan rupees (PKR) & - \\
\hline Distance to market & Access of households to the market & + \\
\hline Land holding & Agricultural land owned by the household & - \\
\hline \multirow[t]{2}{*}{ Livestock value } & Estimated value of livestock in PKR & + \\
\hline & Economic and financial variables & \\
\hline Income agriculture & Worth (in Pakistani currency) & - \\
\hline Income Livestock & Worth (in Pakistani currency) & $+/-$ \\
\hline Income off-farm & Worth (in Pakistani currency) & - \\
\hline Livestock value & Worth (in Pakistani currency) & $+1-$ \\
\hline
\end{tabular}

\subsection{Statistical Analysis}

In our sample, 51 of the 150 sampled households have no income from forests and require techniques in which dependent variables take on only two values. Therefore, logistic regression was used to study the association of households' decisions in depending on forest income and regarding their socio-economic characteristics (Table 2). We used the logit model to predict the probability of a household to depend on forest income and a tobit model to predict the total forest income obtained based on his/her socioeconomic attributes.

The basic form of the logit model is shown in Equation (1).

$$
\operatorname{Logit}(p i)=\ln \left(\frac{p i}{1-p i}\right)=\beta_{0}+\beta_{1} x_{1, i}+\ldots+\beta_{j} x_{j, i}
$$


where (pi) represents the probability of observation $i$ (household) that generated income from forests and $x_{j i}$, is the value of the $j^{\text {th }}$ independent variable for the $i^{\text {th }}$ observation.

The basic form of the tobit model is shown in Equation (2) [47].

$$
\begin{gathered}
y_{i}^{*}=\beta x_{i}+\epsilon_{i} \\
y_{i}= \begin{cases}0 & \text { if } y_{i}^{*} \leq 0, \\
y_{i}^{*} & \text { if } y_{i}^{*} \geq 0,\end{cases}
\end{gathered}
$$

where $X_{i}$ is the explanatory variables, $\beta_{i}$ is the parameter to be estimated, $y_{i}$ is the observed dependent variable, and $y_{i}^{*}$ is the latent variable with a value $>0$.

\section{Results}

\subsection{Sample Overview and Descriptive Statistics}

In our sample of 150 households, $129(86 \%)$ were not members of local JFMCs and only $21(14 \%)$ were members (Table 3$)$. Households with a market distance less of than $1 \mathrm{~km}$, between 1 and $2 \mathrm{~km}$, and greater than $2 \mathrm{~km}$ were $65(43 \%), 80(53 \%)$, and $15(3 \%)$, respectively (Table 3). All the sampled households collected fuelwood both for home use and sale (Table 3). Households in the district heavily depended on livestock production. In total of the 150 households, $99(66 \%)$ households grazed livestock and collected fodder for the livestock in the nearby forested land (Table 3).

Table 3. Descriptive statistics for household basic characteristics and income strategies. Non-normally distributed data is described by the median value and the interquartile range (IQR), representing the range of the central $50 \%$ of the data.

\begin{tabular}{|c|c|c|}
\hline \multirow{2}{*}{ Variables } & \multicolumn{2}{|c|}{ Summary statistics } \\
\hline & Unit & Median (IQR) or Count (\%) \\
\hline \multicolumn{3}{|l|}{ Household's distance } \\
\hline Household member JFMC & Households (\%) & 14 \\
\hline Households dist. Forest $<1$ & Households (Km) & 43.3 \\
\hline Households dist. Forest < 2 (cr. 2) & Households (Km) & 53.3 \\
\hline Households dist. Forest > 2 (cr. 2) & Households (Km) & 3.3 \\
\hline \multicolumn{3}{|l|}{ Household's forest dependency } \\
\hline Households with forest income & Households (\%) & 66 \\
\hline Households graze livestock/fodder & Households (\%) & 66 \\
\hline Households collect medicinal plant & Households (\%) & 28.6 \\
\hline Households extract fuel wood & Households (\%) & 100 \\
\hline \multicolumn{3}{|l|}{ Household demographic } \\
\hline Household headcount & Headcount (IQR) & 12 \\
\hline Male/female ratio & Ratio & $1: 1$ \\
\hline Age of head & Years (IQR) & 47 \\
\hline Education & Years (IQR) & $0(14)$ \\
\hline Employed off-farm & Headcount (IQR) & 2 \\
\hline \multicolumn{3}{|l|}{ Household Socio-economic } \\
\hline Ethnicity (Gujar) & Households (\%) & 71.3 \\
\hline Physical assets & PKR (IQR) & 63220 \\
\hline Livestock value & PKR (IQR) & 234100 \\
\hline Cropland area & Acres & 2.059 \\
\hline \multicolumn{3}{|l|}{ Village level characteristics } \\
\hline Forest area & Percentage (\%) & 32.83 \\
\hline Agriculture area & Percentage (\%) & 25.29 \\
\hline
\end{tabular}
Some variables are represented as a count of households and a percentage of the total.

Average household size was 10, higher than the national average (Table 3). Household size is higher due to the prevalent culture of the joint family system. The average age of the head of the household was 47 and the maximum education was 14 years (Table 3). 
However, the majority of the households were illiterate. Job opportunities were limited and families sent members to other cities and the Middle East for jobs. In almost every household, two members worked in off-farm jobs (Table 3).

The majority of households (71\%) belonged to the Gujar caste. They are the most underprivileged people of the area and heavily depend on livestock production. Comparatively fewer respondents belonged to the Khan tribe (Table 3). Most of the forest and agriculture resources of the study area belonged to the Khan tribe. The median values of assets and livestock in Pakistani Rupees (PKR) are given in Table 3. The average agriculture land was 2.059 acre, mostly available in the plain areas of the valley (Table 3).

\subsection{Household Income Sources and Their Relative Contribution}

Households in the target area were involved in a range of livelihood activities that include forest product collection, agriculture, livestock production, and off-farm and nonfarm jobs, as can be seen in Figure 3. Respondent households obtained the largest share of their income from off-farm activities (37\%) and least some from forest product collection (16\%). Crop and livestock produce contributed $25 \%$ and $21 \%$, respectively, to households total income, as can be seen in Figure 3. In the off-farm income category, foreign remittance constituted the biggest share (46\%), followed by wages (34\%), self-employment $(12 \%)$, and salaries and pension (8\%). Given the resource scarcity and harsh environment of the area, foreign remittance and wage employment are the main contributors of respondent households' total income. Fuelwood constituted the biggest share $(66 \%)$ of forest income, followed by a smaller amount of medical plants $(20 \%)$ and fodder $(13 \%)$.

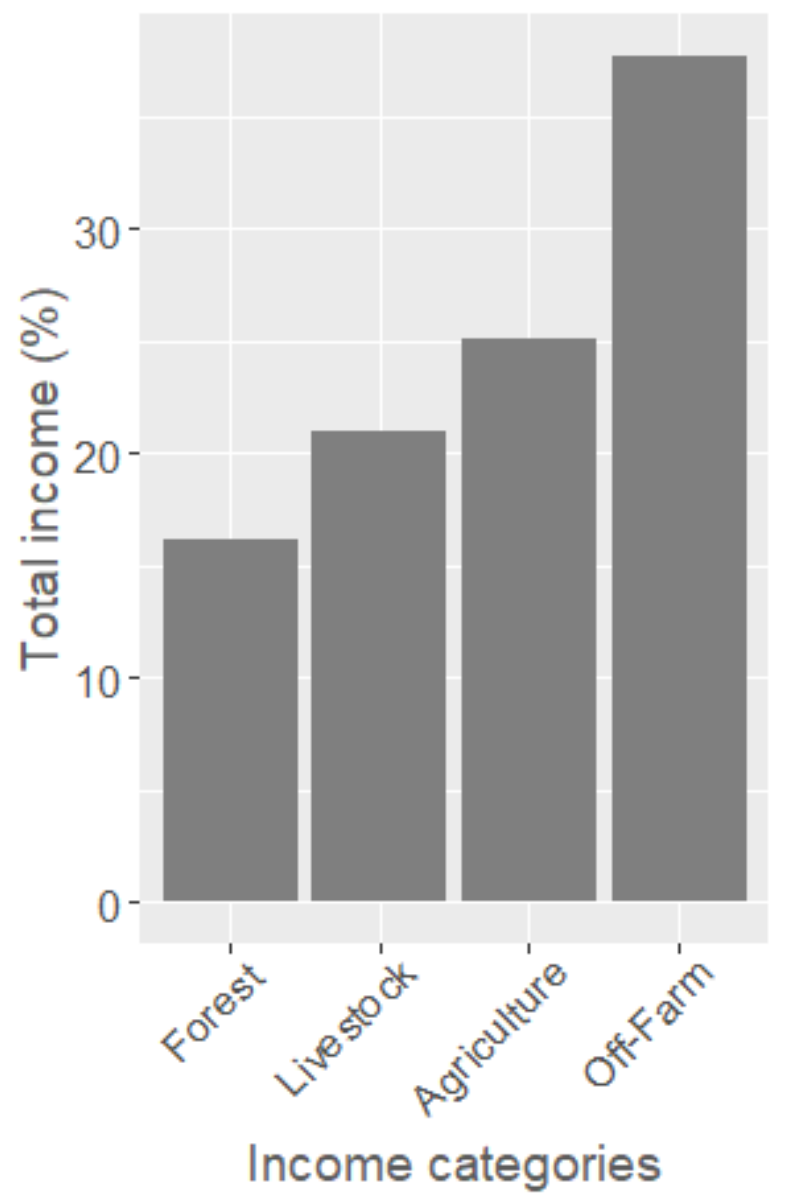

Figure 3. Major sources of household income and their contribution (\%) to the total income. 


\subsection{Regression Analysis}

High multicollinearity can be a source of biased results. Before conducting the regression, we used tolerance $\left(1-R^{2}\right)$ and variance inflation factor (VIF) methods to check for multicollinearity. A tolerance value of less than 0.2 and VIF value greater than 5 indicate high multicollinearity in the model. Our results showed no sign of multicollinearity as the VIF of all the explanatory variables were less than 3.3 and the tolerance value was greater than 0.2 . We also used receiver operating characteristics (ROC) to validate the performance of our model, a common method to assess the performance of a binary classifier. The area under the ROC curve was 0.87 , the value falling in the excellent model performance range. The Hosmer and Lemeshow test for the binary logistic regression showed that there was no statistical difference between the predicted and observed values, indicating a good fit of the models with a $p$-value of 0.07 (>0.05).

In the case of household decision making behavior, our model (logit) revealed that variables such as a member employed off-farm, physical assets, and off-farm income showed a statistically significant and negative association with households' decision to depend on forest income (Table 4). For example, the probability of a family to depend on forests for income decreased by $271 \%(p>0.001)$ following a member doing additional labor in the off-farm sector. Similarly, the likelihood of a household to rely on forests for income decreased by $89 \%(p>0.000)$ following a unit increase in their physical assets (Table 4). Total off-farm income is also negatively correlated and the probability of a household to depend on forest income decreased by $26 \%(p>0.000)$ following a unit increase in off-farm income (Table 4). However, household size showed a positive association with households' decision to depend on forest income. The odds of households to depend on forest income increased by $58 \%(p>0.000)$ following a unit increase in household size.

Table 4. Results of the regression analysis for factors influencing household decision-making behaviors to rely on forests for income (logit) and total income extracted (tobit). Values in parentheses are the standard error (SE). The variable JFMC has a value of 1 if the household is a member of a JFMC and is 0 otherwise. The variable ethnicity has a value of 1 if the household belongs to the Khan ethnic group. The reference category of distances to the market is $<1 \mathrm{~km}$.

\begin{tabular}{|c|c|c|c|c|c|c|}
\hline \multirow{3}{*}{ Variables } & \multicolumn{3}{|c|}{ Logit Model } & \multicolumn{3}{|c|}{ Tobit Model } \\
\hline & Parameter & Standard & Odds & Parameter & Standard & Odd \\
\hline & Estimate & Error & Ratio & Estimate & Error & Ratio \\
\hline Intercept & 0.245 & & & 8.652 & & \\
\hline Distance from market $(1-2 \mathrm{~km})$ & 0.789 & 0.774 & 2.20 & -0.003 & $(0.001)$ & $0.19 * *$ \\
\hline Distance from market (>2 km) & -1.595 & 2.226 & 0.20 & -0.0001 & $(0.004)$ & $0.34^{* * *}$ \\
\hline JFMC (membership) & -1.776 & 1.134 & 0.16 & -0.007 & $(0.001)$ & $0.10 * *$ \\
\hline Member employed off-farm & -1.314 & 0.448 & $3.71^{* *}$ & -0.001 & $(0.070)$ & $1.85 * *$ \\
\hline Ethnicity (Khan tribe) & 0.0155 & 1.035 & 1.01 & 0.038 & $(0.001)$ & 0.39 \\
\hline Family type (joint) & -0.366 & 0.887 & 0.69 & 0.001 & $(0.001)$ & 1.04 \\
\hline Household size & 0.855 & 0.2511 & $0.42^{* * *}$ & 0.001 & $(0.040)$ & 1.35 \\
\hline Total agriculture land (acers) & 0.194 & 0.232 & 1.21 & 0.444 & $(0.044)$ & 1.01 \\
\hline Physical assets (Rs) & -0.002 & 0.007 & $0.89^{* * *}$ & -0.469 & $(0.092)$ & $0.62 * * *$ \\
\hline Livestock value (Rs) & -0.0007 & 0.0006 & 1.09 & -0.002 & $(0.004)$ & 0.99 \\
\hline Agriculture income (Rs) & 0.001 & 0.006 & 1.00 & 0.001 & $(0.010)$ & 1.00 \\
\hline Off-farm income (Rs) & -0.0007 & 0.0007 & $1.26^{* * *}$ & -0.067 & $(0.009)$ & $0.93^{* * *}$ \\
\hline Livestock income (Rs) & -0.0004 & 0.0004 & 0.85 & -0.005 & $(0.007)$ & 0.99 \\
\hline Fuel extraction $(\mathrm{kg})$ & 0.002 & 0.0009 & 1.02 & 0.112 & $(0.125)$ & 0.00 \\
\hline Household education & 0.049 & 0.083 & 1.05 & -0.102 & $(0.014)$ & 0.00 \\
\hline Household age & -0.037 & 0.032 & 0.96 & -0.324 & $(0.472)$ & 0.10 \\
\hline
\end{tabular}

Note: ${ }^{* *} p<0.05 ;{ }^{* * *} p<0.01$.

In the case of households' total income from forests, our model (tobit) revealed that variables such as household distance to the market, membership to a JFMC, members employed off-farm, physical assets, and off-farm income all showed significant and negative associations to the total income obtained from the forest (Table 4). For example, the 
likelihood of a household depending on forests for income decreased by $81 \%(p>0.00)$ following a unit increase in the market distance in the range of between 1 and $2 \mathrm{~km}$, and decreased by $66 \%(p>0.000)$ following a unit increase in the market distance in the range beyond $2 \mathrm{~km}$ (Table 4). Similarly, the probability of households' dependency on forests for income when member was part of a JFMC decreased by $90 \%(p>0.001)$. Similarly, the odds of forest income dependency of a household decreased by $85 \%(p>0.001), 38 \%$ $(p>0.000)$, and $7 \%(p>0.000)$ when an additional family member was employed off-farm, when there was a unit increase in the physical assets, and when they received income from the off-farm sector, respectively.

\section{Discussion}

\subsection{Household Size and Forest Income}

According to the data, average family size is higher than the national average (7.5). Majority of the households are living in joint families and the maximum household size reported was 30 members in a family. Our results suggest that the probability of households to rely on forests for income is high for bigger families. However, in the tobit model, the household size revealed to be insignificant. A plausible explanation could be that the decision to rely on forests for income depends on household size but the actual collection of forest-based products depend on the number of children and females in the household. In addition, in forest-dependent communities, large families may have a higher propensity to extract forest resources to meet their subsistence needs rather than to sell. As compared to other NTFPs, fuelwood in the study area contributed the highest proportion of income to the household economy. The decision to allocate part of their labor force for forest resource extraction could be reliant on the labor availability in big families. Due to poverty and lack of high paying jobs, children and females in the family work in order to meet the expenses. For households living close to forests, the easy and available job for children and females is fuelwood collection. In contrast, adult males are mostly engaged in off-farm jobs.

These results correspond to the findings of other studies relating household size with forest dependency for income [2,3,48-52].

\subsection{Off-Farm Employment and Forest Income}

Our results confirmed that families with more members in off-farm jobs depend less on forest income and resultantly obtain less income from forests (Table 2). The negative effect of off-farm employment on households' decision to not rely on forest income and extract less income from forests is probably due to the fact that households with more off-farm income employment opportunities and work are able to meet their expenses easily from other sources while depending less on forests. These results are also consistent with other studies conducted on forest-dependent communities [53,54] They found that households receiving off-farm income were less likely to involved in forest product collection. This may be because high remuneration in the off-farm sector makes income from forest extraction less attractive. In addition, off-farm income generation opportunities create labor competition, in which time spent in wage labor mean less time is available for forest resource extraction. These results are also supported by other studies [19,52]. They reported that off-farm employment increases the probability of households to depend less on forest income and thereby extract less income from forests.

\subsection{Households' Assets Status and Forest Income}

The association between the value of households' asset status and forest dependence is vague. Some studies argued that asset-poor households are more forest dependent than rich and middle-income households [22,52]. However, other studies showed that richer households earn significantly more income from forests than the poor and middle-income groups $[3,48,49]$. Our results showed that households with more physical assets tend to rely less on forest resource extraction. The low dependence of households with more physical assets on forest income may be because households with more physical assets have access 
to other sources of income than the forests $[55,56]$. These results are in line with the finding of [57] who found that households with more assets depend less on forest income and extract less income from forests. The findings were also consistent in all five sub-divisions of the district (Table 4). Generally, poor people in the area are natural resource-dependent and jobless members of the households, complementing their income through fuelwood sale. In contrast, rich households are more likely to have financial resources to invest in other high-paying opportunities.

\subsection{Households' Off-Farm and Forest Income}

Off-farm income is a very important variable shaping households' decision of depending on forest resources [17]. Our results showed that households with greater off-farm income were more likely to extract less income from forests and were less likely to depend on forest income (Table 5). This may be because farmers with greater income from other sources may be engaged in other activities with less dependence on forests for income. This result is in agreement with the findings of $[17,58]$ who also observed a negative and significant relationship between off-farm income and farmers' decision to depend on forest income, extracting more income from forests.

Table 5. Household income classes and percentage contribution of various livelihood strategies.

\begin{tabular}{|c|c|c|c|c|c|c|}
\hline \multirow{2}{*}{ Sub-Division } & \multirow{2}{*}{$\begin{array}{l}\text { Annual Income } \\
\text { (‘000 pkr) }\end{array}$} & \multirow{2}{*}{$\begin{array}{c}\text { Percentage of } \\
\text { RESPONDENTS }\end{array}$} & \multicolumn{4}{|c|}{ Contribution to Household Income (\%) } \\
\hline & & & Crops & Livestock & Forest & Off-Farm \\
\hline \multirow{4}{*}{ Behrain } & $<250$ & 37.5 & 25.06 & 22.08 & 19.27 & 33.59 \\
\hline & $250-350$ & 35 & 27.8 & 24.3 & 17.7 & 30.2 \\
\hline & $350-450$ & 20 & 29.8 & 21.6 & 12.4 & 36.2 \\
\hline & $>450$ & 7.5 & 35.54 & 19.72 & 8.73 & 36.01 \\
\hline \multirow{4}{*}{ K. Khela } & $<250$ & 13.8 & 26.3 & 21.7 & 18.9 & 33.1 \\
\hline & $250-350$ & 41.6 & 29.6 & 23.1 & 14.4 & 32.9 \\
\hline & $350-450$ & 16.6 & 27.7 & 25.6 & 10.6 & 36.1 \\
\hline & $>450$ & 36.8 & 30.6 & 24.9 & 7.4 & 37.1 \\
\hline \multirow{4}{*}{ Kabal } & $<250$ & 24 & 20.3 & 23.7 & 19.1 & 36.9 \\
\hline & $250-350$ & 16 & 22.0 & 26.2 & 13.1 & 38.7 \\
\hline & $350-450$ & 20 & 25.5 & 25.3 & 10.2 & 39.0 \\
\hline & $>450$ & 40 & 27.3 & 25.7 & 6.1 & 40.9 \\
\hline \multirow{4}{*}{ Matta } & $<250$ & 44.82 & 30.3 & 21.5 & 17.3 & 30.9 \\
\hline & $250-350$ & 24.13 & 28.5 & 19.4 & 12.2 & 39.9 \\
\hline & $350-450$ & 20.68 & 25.1 & 22.4 & 9.5 & 43.0 \\
\hline & $>450$ & 10.34 & 26.7 & 20.2 & 4.4 & 48.7 \\
\hline \multirow{4}{*}{ Barikot } & $<250$ & 40 & 29.6 & 23.3 & 14.5 & 32.6 \\
\hline & $250-350$ & 30 & 31.2 & 22.7 & 10.3 & 35.8 \\
\hline & $350-450$ & 20 & 28.9 & 19.1 & 6.3 & 45.7 \\
\hline & $>450$ & 10 & 32.5 & 16.8 & 3.9 & 46.8 \\
\hline
\end{tabular}

People living in the peripheral villages of forest are extremely poor and depend on natural resources for their survival. The biggest source of forest income in the study area is fuelwood sale. Programs providing alternatives to the reliance on fuelwood and providing environmentally friendly off-farm income generation schemes designed for the poorest households would not only reduce pressure on forests but would also improve the livelihood of the local people. 


\subsection{Household Distance to the Market and Forest Income}

Households close to the market obtained the least income from forests and households away from the market obtained the highest, as can be seen in Figure 4. Our result of negative association of market access with forest income is consistent with previous studies $[59,60]$. When local communities are integrated to outside markets, they depend less on environmental resources due to the high opportunity cost of collection [56,61]. In remote rural areas of Pakistan in which access to external markets is limited due to poor infrastructure facilities, people depend on the nearby forested land for income. In contrast, town adjacent communities may have a wide range of job options, such as employment in permanent jobs and small businesses.

\section{Households's distance to market}
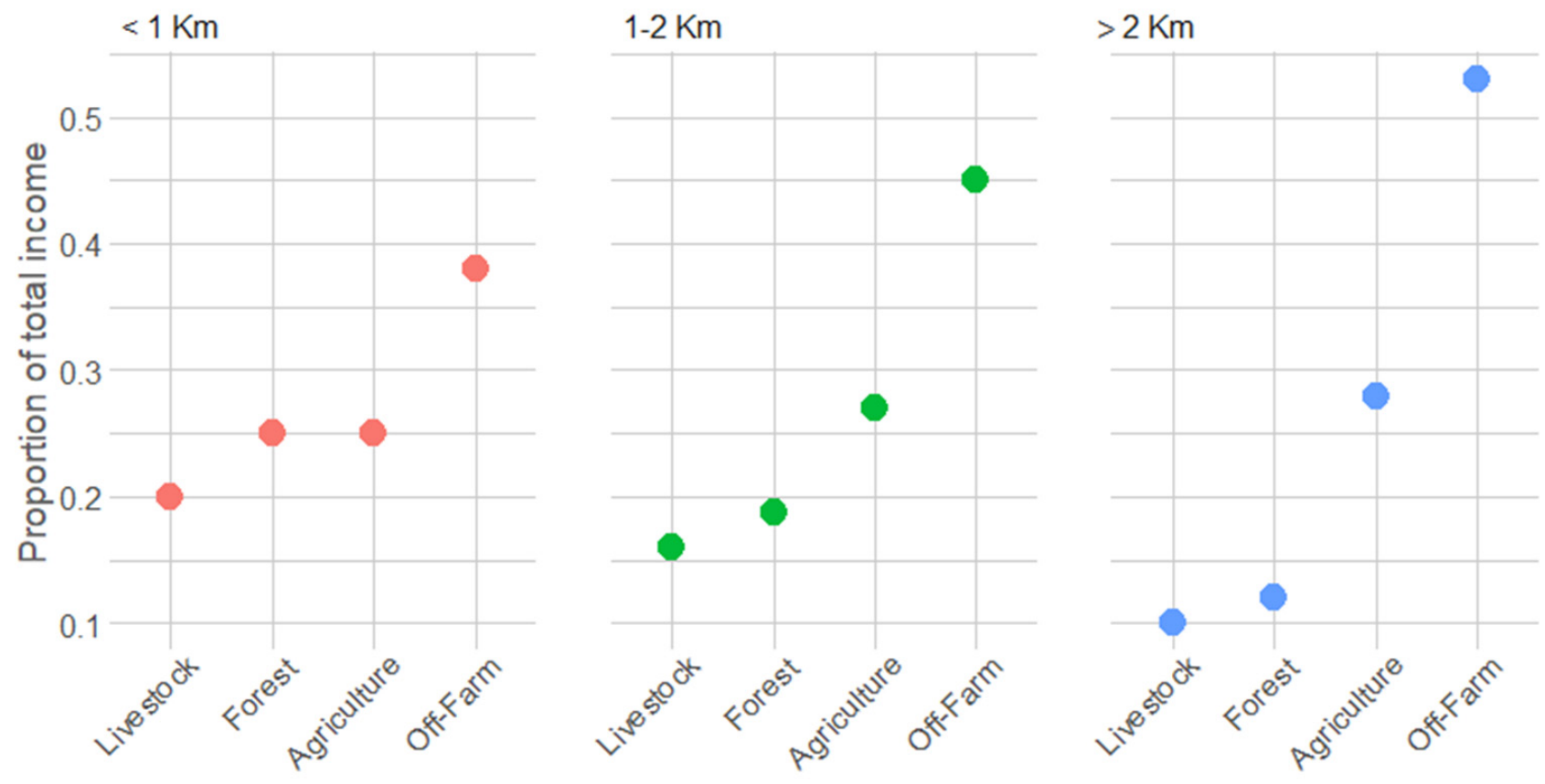

Income categories

Figure 4. Distance to market and income proportion obtained from various income sources.

Another possible explanation for the negative association between distance from the market and forest income could be the transportation cost of fuelwood sale. Living further from the market mean less income from fuelwood sales. In addition, this negative association seems to be well supported by the von Thünen theory of land rent, which proposes a higher return to agriculture and wage labor in areas closer to the town market than in remote areas. This result is also in line with the views of $[3,62]$ regarding that higher rural wages and higher off-farm income opportunities slow deforestation rates through lessening the pressure on forests for income use.

\subsection{Household Membership to JFMCs and Forest Income}

Membership to joint forest management committees (JFMCs) enables farmers to depend less on forest resources for livelihoods and income [63]. Our results show that households' membership to JFMCs negatively influence their dependence on forests and they obtain relatively less income from forests as compared to non-members. The probable reasons could be that the members of JFMCs may be more mindful of forest resources and actively involved in their protection. They may be wealthy, educated, and more conscious to forest resource protection. Our results endorsed the findings of prior studies by $[18,64,65]$ 
as they stated that membership to JFMCs ensures effective forest resource management through reduced dependence on forests for income; see Figure 5.

\section{Household's Membership}

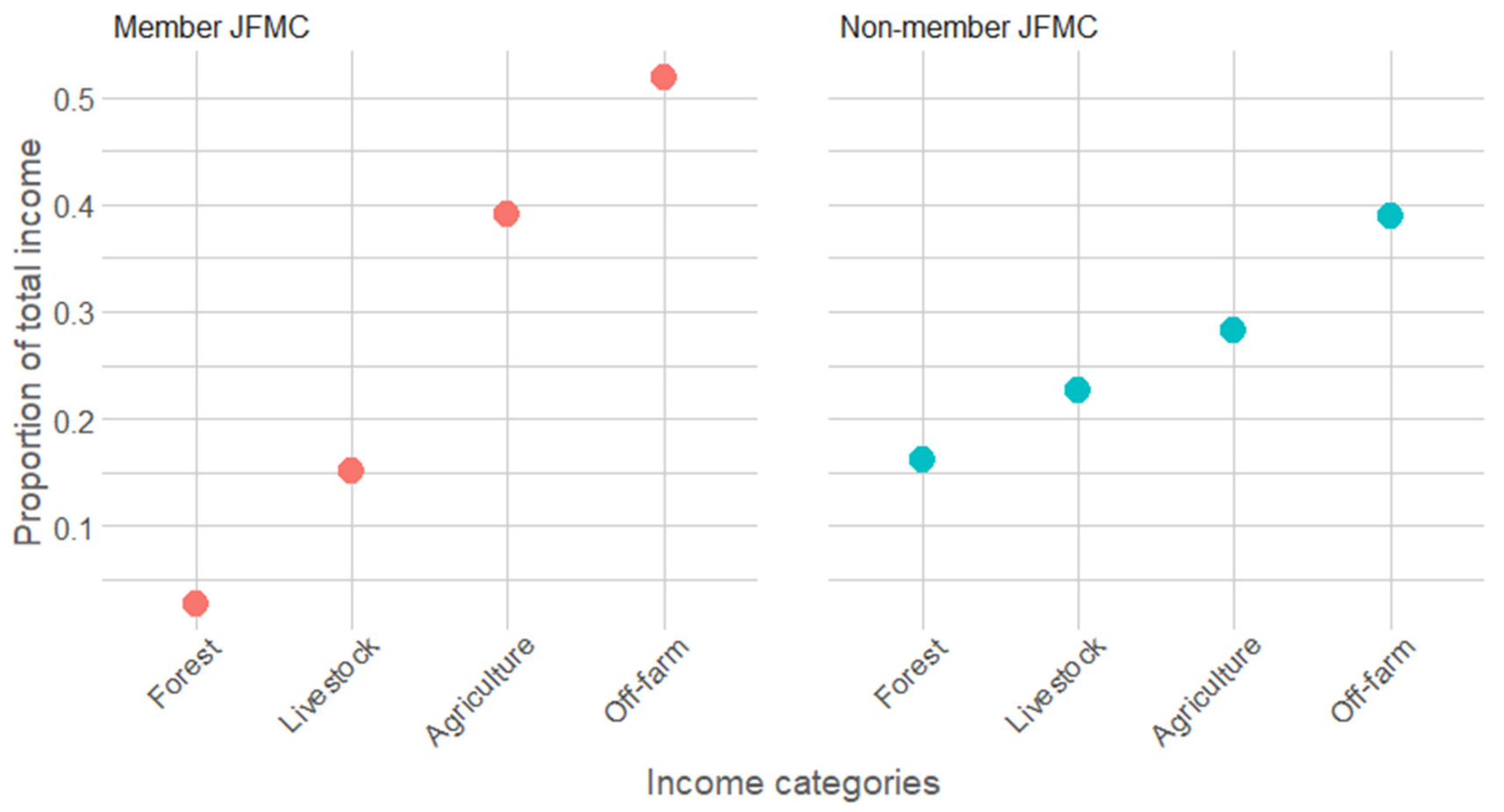

Figure 5. Households' membership to JFMCs and income proportion obtained from various income sources.

\section{Conclusions and Recommendations}

Forests plays a significant role in the income of rural households in the $\mathrm{HKH}$ region of Pakistan. However, over-extraction of forest products for income purposes resulted in deforestation in the region. This study assessed the households' decision-making behaviors in depending on income from nearby forested land using socio-economic attributes. The analysis may contribute to the understanding of how forest management policies might be designed or how existing policies may be improved or better targeted towards families that depend on forests for income.

We found that households with more members in off-farm jobs and more income from the off-farm sector depend less on forests for income. Similarly, rich households with membership to local JFMCs also depend less on forest resources. Big families living close to forests and away from markets depend more on forests for income. However, family size affects their decision to rely on forests but this does not affect the total income extraction from forests.

Government intervention for promoting off-farm employment and other environmentally friendly business activities such as NTFPs collection and fishery developments would also contribute to households' decision to depend less on forests for income and obtain less income from forests. The provision of alternative energy sources such as hydroelectric power and subsidized LPG (liquid petroleum gas) to meet the needs of fuelwood will greatly reduce the pressure on forest resources.

Women and children in the area are the main labor for forest income. Initiatives targeted at the empowerment of women through promotion of local handicrafts and other small home-based businesses would greatly increase their opportunity cost of forest resource extraction. Forestry extension staff should include local people in the management of forests through the establishment of JFMCs as this would give a sense of ownership to local people, which will ultimately lessen the protection of jobs in the forest department. 
Author Contributions: Conceptualization, M.B., A.Z., and A.U.; methodology, M.B.; software, A.Z.

and A.U.; validation, H.K.; formal analysis, M.B., A.Z. and A.U.; investigation, M.B.; resources, A.U.; writing—original draft preparation, M.B.; writing—review and editing, A.Z., A.U. and H.K.; visualization, H.K.; supervision, H.K.; funding acquisition, A.U. All authors have read and agreed to the published version of the manuscript.

Funding: The publication of this article is funded by the Open Access Fund of the Leibniz Association to Ayat Ullah.

Conflicts of Interest: The authors declare no conflict of interest

\section{References}

1. Lowore, J.; Meaton, J.; Wood, A. African forest honey: An overlooked NTFP with potential to support livelihoods and forests. Environ. Manag. 2018, 62, 15-28. [CrossRef]

2. Zeb, A.; Hamann, A.; Armstrong, G.W.; Acuna-Castellanos, D. Identifying local actors of deforestation and forest degradation in the Kalasha valleys of Pakistan. For. Policy Econ. 2019, 104, 56-64. [CrossRef]

3. Angelsen, A.; Jagger, P.; Babigumira, R.; Belcher, B.; Hogarth, N.J.; Bauch, S.; Wunder, S. Environmental income and rural livelihoods: A global-comparative analysis. World Dev. 2014, 64, S12-S28. [CrossRef] [PubMed]

4. Wunder, S.; Angelsen, A.; Belcher, B. Forests, livelihoods, and conservation: Broadening the empirical base. World Dev. 2014, 64, S1-S11. [CrossRef]

5. Ali, A. Forest-based livelihoods, income, and poverty: Empirical evidence from the Himalayan region of rural Pakistan. J. Rural. Stud. 2018, 57, 44-54. [CrossRef]

6. Ahammad, R.; Stacey, N.; Sunderland, T.C. Use and perceived importance of forest ecosystem services in rural livelihoods of Chittagong Hill Tracts, Bangladesh. Ecosyst. Serv. 2019, 35, 87-98. [CrossRef]

7. Schreckenberg, K.; Poudyal, M.; Mace, G. Ecosystem Services and Poverty Alleviation: Trade-offs and Governance; Taylor \& Francis: Boca Raton, FL, USA, 2018; p. 352.

8. Sandhu, H.; Sandhu, S. Poverty, development, and Himalayan ecosystems. Ambio 2015, 44, 297-307. [CrossRef] [PubMed]

9. Adam, Y.O.; Pretzsch, J.; Pettenella, D. Contribution of non-timber forest products livelihood strategies to rural development in drylands of Sudan: Potentials and failures. Agric. Syst. 2013, 177, 90-97. [CrossRef]

10. Schaafsma, M.; Morse-Jones, S.; Posen, P.; Swetnam, R.D.; Balmford, A.; Bateman, I.J.; Burgess, N.B.; Chamshama, S.A.O.; Fisher, B.; Freeman, T.; et al. The importance of local forest benefits: Economic valuation of Non-Timber Forest Products in the Eastern Arc Mountains in Tanzania. Glob. Environ. Chang. 2014, 24, 295-305. [CrossRef]

11. Rasmussen, L.V.; Watkins, C.; Agrawal, A. Forest contributions to livelihoods in changing agriculture-forest landscapes. For. Policy Econ. 2017, 84, 1-8. [CrossRef]

12. Amare, D.; Mekuria, W.; Wondie, M.; Teketay, D.; Eshete, A.; Darr, D. Wood extraction among the households of Zege Peninsula, Northern Ethiopia. Ecol. Econ. 2017, 142, 177-184. [CrossRef]

13. Chopra, K. The valuation and pricing of non-timber forest products: Conceptual issues and a case study from India. In Environmental Sustainability. Practical Global Applications; Taylor \& Francis: Boca Raton, FL, USA, 2019; pp. 114-146.

14. Uberhuaga, P.; Smith-Hall, C.; Helles, F. Forest income and dependency in lowland Bolivia. Environ. Dev. Sustain. 2012, 14, 3-23. [CrossRef]

15. Aung, P.S.; Adam, Y.O.; Pretzsch, J.; Peters, R. Distribution of forest income among rural households: A case study from Natma Taung national park, Myanmar. For. Trees Livelihoods 2015, 24, 190-201. [CrossRef]

16. Garekae, H.; Thakadu, O.T.; Lepetu, J. Socio-economic factors influencing household forest dependency in Chobe enclave, Botswana. Ecol. Process. 2017, 6, 40. [CrossRef]

17. Hussain, J.; Zhou, K.; Akbar, M.; Zafar khan, M.; Raza, G.; Ali, S.; Hussain, A.; Abbas, Q.; Khan, G.; Khan, M.; et al. Dependence of rural livelihoods on forest resources in Naltar Valley, a dry temperate mountainous region, Pakistan. Glob. Ecol. Conserv. 2019, 20, e00765. [CrossRef]

18. Ullah, A.; Sam, A.S.; Sathyan, A.R.; Mahmood, N.; Zeb, A.; Kächele, H. Role of Local Communities in Forest Landscape Restoration: Key Lessons from the Billion Trees Afforestation Project, Pakistan. Sci. Total Environ. 2021, 772, 145613. [CrossRef] [PubMed]

19. Zeb, A.; Armstrong, G.W.; Hamann, A. Forest conversion by the indigenous Kalasha of Pakistan: A household level analysis of socioeconomic drivers. Glob. Environ. Chang. 2019, 59, 102004. [CrossRef]

20. Parvathi, P.; Nguyen, T.T. Is environmental income reporting evasive in household surveys? Evidence from rural poor in Laos. Ecol. Econ. 2018, 143, 218-226. [CrossRef]

21. Damania, R.; Joshi, A.; Russ, J. India's forests-Stepping stone or millstone for the poor? World Dev. 2020, 125, 104451. [CrossRef]

22. Zeb, A. Spatial and temporal trends of forest cover as a response to policy interventions in the district Chitral, Pakistan. Appl. Geogr. 2019, 102, 39-46. [CrossRef]

23. Hasan, L. An anatomy of state failures in forest management in Pakistan. Pak. Dev. Rev. 2007, 46, 1189-1203. [CrossRef]

24. Irland, L.C. State failure, corruption, and warfare: Challenges for forest policy. J. Sustain. For. 2008, 27, 189-223. [CrossRef] 
25. Tumusiime, D.M.; Byakagaba, P.; Tweheyo, M. Policy and Institutional Drivers of Deforestation. Environ. Policy Law 2018, 48, 137-144. [CrossRef]

26. Brandt, J.S.; Allendorf, T.; Radeloff, V.; Brooks, J. Brooks Effects of National Forest-management Regimes on Unprotected Forests of the Himalaya. Conserv. Biol. 2017, 31, 1271-1282. [CrossRef] [PubMed]

27. Cuni-Sanchez, A.; Ngute, A.S.K.; Sonké, B.; Sainge, M.N.; Burgess, N.D.; Klein, J.A.; Marchant, R. The importance of livelihood strategy and ethnicity in forest ecosystem services' perceptions by local communities in north-western Cameroon. Ecosyst. Serv. 2019, 40, 101000. [CrossRef]

28. Robinson, B.E.; Zheng, H.; Peng, W. Disaggregating livelihood dependence on ecosystem services to inform land management. Ecosyst. Serv. 2019, 36, 100902. [CrossRef]

29. Qasim, M.; Hubacek, K.; Termansen, M. Underlying and proximate driving causes of land use change in district Swat, Pakistan. Land Use Policy 2013, 34, 146-157. [CrossRef]

30. Ali, J.; Benjaminsen, T.A. Fuelwood, timber and deforestation in the Himalayas. Mt. Res. Dev. 2004, 24, 312-318. [CrossRef]

31. Ali, J.; Benjaminsen, T.A.; Hammad, A.A.; Dick, Ø.B. The road to deforestation: An assessment of forest loss and its causes in Basho Valley, Northern Pakistan. Glob. Environ. Chang. 2005, 15, 370-380. [CrossRef]

32. Ali, T.; Ahmad, M.; Shahbaz, B.; Suleri, A. Impact of participatory forest management on vulnerability and livelihood assets of forest-dependent communities in northern Pakistan. Int. J. Sustain. Dev. World Ecol. 2007, 14, 211-223. [CrossRef]

33. Shahbaz, B.; Mbeyale, G.; Haller, T. Trees, trust and the state: A comparison of participatory forest management in Pakistan and Tanzania. J. Int. Dev. J. Dev. Stud. Assoc. 2008, 20, 641-653. [CrossRef]

34. Khan, S.R.; Khan, S.R. Assessing poverty-deforestation links: Evidence from Swat, Pakistan. Ecol. Econ. 2009, 68, 2607-2618. [CrossRef]

35. Ellis, F.; Freeman, H.A. Rural livelihoods and poverty reduction strategies in four African countries. J. Dev. Stud. 2004, 40, 1-30. [CrossRef]

36. Ellis, F. The determinants of rural livelihood diversification in developing countries. J. Agric. Econ. 2000, 51, 289-302. [CrossRef]

37. Ellis, F. Livelihoods Approach to Migration and Poverty Reduction; Contract No: CNTR 034890 2003; Paper Commissioned by the Department for International Development (DFID): London, UK, 2003.

38. Sayer, J.; Campbell, B.; Petheram, L.; Aldrich, M.; Perez, M.R.; Endamana, D. Assessing environment and development outcomes in conservation landscapes. Biodivers. Conserv. 2007, 16, 2677-2694. [CrossRef]

39. Babigumira, R.; Angelsen, A.; Buis, M.; Bauch, S.; Sunderland, T.; Wunder, S. Forest clearing in rural livelihoods: Household-level global-comparative evidence. World Dev. 2014, 64, S67-S79. [CrossRef]

40. De Haan, L.; Zoomers, A. Exploring the frontier of livelihoods research. Dev. Chang. 2005, 36, 27-47. [CrossRef]

41. Shahbaz, B.; Ali, T.; Suleri, A.Q. Dilemmas and challenges in forest conservation and development interventions: Case of Northwest Pakistan. For. Policy Econ. 2011, 13, 473-478. [CrossRef]

42. Sunderlin, W.D.; Angelsen, A.; Belcher, B.; Burgers, P.; Nasi, R.; Santoso, L.; Wunder, S. Livelihoods, forests, and conservation in developing countries: An overview. World Dev. 2005, 33, 1383-1402. [CrossRef]

43. Nielsen, Ø.J.; Rayamajhi, S.; Uberhuaga, P.; Meilby, H.; Smith-Hall, C. Quantifying rural livelihood strategies in developing countries using an activity choice approach. Agric. Econ. 2013, 44, 57-71. [CrossRef]

44. DfID, U.K. Sustainable Livelihoods Guidance Sheets; DFID: London, UK, 1999; p. 445.

45. Qasim, M.; Hubacek, K.; Termansen, M.; Khan, A. Spatial and temporal dynamics of land use pattern in District Swat, Hindu Kush Himalayan region of Pakistan. Appl. Geogr. 2011, 31, 820-828. [CrossRef]

46. Pan, W.; Carr, D.; Barbieri, A.; Bilsborrow, R.; Suchindran, C. Forest clearing in the Ecuadorian Amazon: A study of patterns over space and time. Popul. Res. Policy Rev. 2007, 26, 635-659. [CrossRef] [PubMed]

47. Gujarati, D.N. Basic Econometrics, 4th ed.; McGraw-Hill/Irwin: New York, NY, USA, 2003.

48. Vedeld, P.; Angelsen, A.; Bojö, J.; Sjaastad, E.; Berg, G.K. Forest environmental incomes and the rural poor. For. Policy Econ. 2007, 9, 869-879. [CrossRef]

49. Kamanga, P.; Vedeld, P.; Sjaastad, E. Forest incomes and rural livelihoods in Chiradzulu District, Malawi. Ecol. Econ. 2009, 68, 613-624. [CrossRef]

50. Tesfaye, Y.; Roos, A.; Campbell, B.; Bohlin, F. Forest income and poverty alleviation under participatory forest management in the Bale Highlands, South Ethiopia. Int. For. Rev. 2010, 12, 558-577. [CrossRef]

51. Tumusiime, D.M.; Vedeld, P.; Gombya-Ssembajjwe, W. Breaking the law? Illegal livelihoods from a protected area in Uganda. For. Policy Econ. 2011, 13, 273-283. [CrossRef]

52. Asfaw, A.; Lemenih, M.; Kassa, H.; Ewnetu, Z. Importance, determinants and gender dimensions of forest income in eastern highlands of Ethiopia: The case of communities around Jelo Afromontane forest. For. Policy Econ. 2013, 28, 1-7. [CrossRef]

53. Dib, J.B.; Alamsyah, Z.; Qaim, M. Land-use change and income inequality in rural Indonesia. For. Policy Econ. 2018, $94,55-66$. [CrossRef]

54. Vasco, C.; Bilsborrow, R.; Torres, B.; Griess, V. Agricultural land use among mestizo colonist and indigenous populations: Contrasting patterns in the Amazon. PLoS ONE 2018, 13, e0199518. [CrossRef]

55. Ullah, A.; Mahmood, N.; Zeb, A.; Kächele, H. Factors Determining Farmers' Access to and Sources of Credit: Evidence from the Rain-Fed Zone of Pakistan. Agriculture 2020, 10, 586. [CrossRef] 
56. Ullah, A.; Arshad, M.; Kächele, H.; Zeb, A.; Mahmood, N.; Müller, K. Socio-economic analysis of farmers facing asymmetric information in inputs markets: Evidence from the rainfed zone of Pakistan. Technol. Soc. 2020, 63, 101405. [CrossRef]

57. Lax, J.; Köthke, M. Livelihood strategies and forest product utilisation of rural households in Nepal. Small-Scale For. 2017, 16, 505-520. [CrossRef]

58. Härtl, F.H.; Paul, C.; Knoke, T. Cropping systems are homogenized by off-farm income-Empirical evidence from small-scale farming systems in dry forests of southern Ecuador. Land Use Policy 2019, 82, 204-219. [CrossRef]

59. Horn, C.M.; Gilmore, M.P.; Endress, B.A. Ecological and socio-economic factors influencing aguaje (Mauritia flexuosa) resource management in two indigenous communities in the Peruvian Amazon. For. Ecol. Manag. 2012, 267, 93-103. [CrossRef]

60. Melaku, E.; Ewnetu, Z.; Teketay, D. Non-timber forest products and household incomes in Bonga forest area, southwestern Ethiopia. J. For. Res. 2014, 25, 215-223. [CrossRef]

61. Ullah, A.; Arshad, M.; Kächele, H.; Khan, A.; Mahmood, N.; Müller, K. Information asymmetry, input markets, adoption of innovations and agricultural land use in Khyber Pakhtunkhwa, Pakistan. Land Use Policy 2020, 90, 104261. [CrossRef]

62. Angelsen, A.; Kaimowitz, D. Rethinking the causes of deforestation: Lessons from economic models. World Bank Res. Obs. 1999, 14, 73-98. [CrossRef]

63. Basnet, S.; Sharma, P.; Timalsina, N.; Khaine, I. Community Based Management for Forest Conservation and Livelihood Improvement: A Comparative Analysis from Forests in Myanmar. J. For. Livelihood 2018, 17, 16-33.

64. Finley-Brook, M. Indigenous land tenure insecurity fosters illegal logging in Nicaragua. Int. For. 2007, 9, 850-864. [CrossRef]

65. Robinson, B.E.; Holland, M.B.; Naughton-Treves, L. Does secure land tenure save forests? A meta-analysis of the relationship between land tenure and tropical deforestation. Glob. Environ. Chang. 2013, 29, 281-293. [CrossRef] 